\title{
Currency Unions, the Phillips Curve, and Stabilization Policy: Some Suggestions for Europe
}

\author{
Thomas I. Palley*
}

This paper examines the implications of a currency union for monetary policy. The formation of a currency union worsens the inflation-unemployment tradeoff, so that leaving the inflation target unchanged at its pre-currency union level generates increased unemployment. Geographically based fiscal automatic stabilizers can improve the inflation-unemployment trade-off, which has bearings on the Euro area's Stability and Growth Pact. Financial intermediary balance sheet regulation based on asset-based reserve requirements $(A B R R)$ can provide additional country-specific policy instruments. ABRR alleviate the targets and instruments problem afflicting the monetary authority in a currency union context. This is important for the European Central Bank, which is trying to manage divergent country growth rates with a single interest rate instrument.

JEL classification: ES

Keywords: currency unions, Phillips curve, monetary policy, fiscal policy, asset based reserve requirements

\section{Introduction}

This paper examines the implications of formation of a currency union for the conduct of monetary stabilization policy, with a particular focus on Euroland. Since January 1999 eleven countries in Europe (Austria, Belgium, Finland, France, Germany, Ireland, Italy, Luxembourg, Portugal, Spain, and the Netherlands) have shared a common currency, and

* Washington, DC. A short non-technical version of this paper was published earlier as "Monetary Policy in a Non-Optimal Currency Union: Lessons for the European Central Bank«, in: Rochon, LouisPhillipe/Seccareccia, Mario (eds.) (2003), Dollarization: Lessons from Europe and North America, London / New York: Routledge, pp. 92-Ioo.

Correspondence Address:

Dr. Thomas I. Palley, Principal, Economics of Democratic and Open Societies, Washington, DC 20oIo, USA, e-mail: mail@thomaspalley.com

Received 30 Jan 2006, accepted 05 Jul 2006

C INTERVENTION 3 (2), 2006, 351-369 
Greece became the twelfth member country when it joined the Euro on January I, 200I. Prior to the Euro's introduction there was extensive debate over whether the eleven constituted an optimal currency area. The general consensus was that by the standards laid out in the Mundell (1961)-McKinnon (1963)-Kenen (1969) literature on optimum currency areas, they did not. ${ }^{I}$ Despite this, European politicians still concluded that a currency union was worthwhile because of the political benefits it stood to confer.

Though there is widespread recognition that Euroland is not an optimum currency area, little attention has been given to what this implies for the conduct of monetary stabilization policy. Instead of focusing on how policy might need to be adjusted, the debate has been conducted as if Euroland were an optimum currency area facing the same issues as those confronting other national policy-makers.

This >business as usual thinking is reflected in the European Central Bank (ECB) policy debate of the last several years. Thus, immediately following the creation of the Euro much attention was paid to policy credibility and institutional design issues concerned with policy accountability and transparency. In addition, there was much debate about whether the ECB should adopt inflation targeting, and if so what that target should be. The outcome has been the adoption of an inflation target for the Euro area's "Harmonized Index of Consumer Prices" (HICP) of below two percent - a target similar to that adopted earlier by the Bundesbank when it set monetary policy in Germany. In selecting this target, no consideration appears to have been given to the fact that Euroland is not an optimum currency area. ${ }^{2}$ The implicit assumption is that monetary policy should be conducted without regard to the fact that it is operating in a non-optimal currency area.

The conventional macroeconomic approach to currency unions is largely empirical, and seeks to estimate optimum Taylor interest rate rules using the dynamic disequilibrium neo-Keynesian AS/AD model (see for example Flaschel et al. 2005). The current paper challenges such thinking, and presents a different approach. The paper presents a multi-country model with downward nominal wage rigidity, and develops a micro-founded Phillips curve within such a framework. It then shows how formation of a currency union worsens the inflation-unemployment trade-off. This implies that leaving the inflation target unchanged at its pre-currency union level will generate increased unemployment.

Next, the paper examines how fiscal automatic stabilizers can be used to improve the inflation-unemployment trade-off in a currency union. This has bearings on the Stability and Growth Pact governing the fiscal policy of Euro countries.

I See Bayoumi/Eichengreen (1993). They report that the group of eleven do not constitute an optimum currency area, but there is also a group of countries centered around Germany that could plausibly constitute an optimum currency area.

2 See Angeloni et al. (1999) who provide an insider's account of the monetary policy strategy of the ECB. Gaspar is the Director General of Research at the ECB, and their article contains no mention of optimum currency area considerations. This absence is likely furthered by understandable institutional considerations whereby the ECB has a political vested interest in denying that Euroland is not an optimal currency area. 
Finally, the paper shows how financial intermediary balance sheet regulation based on asset-based reserve requirements (ABRR) can provide policy-makers with additional country specific instruments. A major problem with currency unions is that member countries surrender national interest rates and exchange rates as policy instruments. Consequently, macroeconomic policy must be conducted over a larger more diverse economic area with fewer policy instruments. ABRR can help alleviate this currency union targets and instruments problem. This is of major significance for the ECB, which is trying to manage divergent growth rates across twelve countries with a single interest rate instrument.

\section{The Economics of Optimum Currency Areas Revisited}

The early literature on optimum currency areas (Mundell I96I, McKinnon 1963, Kenen 1969) concentrated on microeconomic concerns. On the supply side, attention focused on factor markets and the mobility of factors across geographic regions. The more geographically mobile factors are, the more regions correspond to an optimum currency area. The argument is that if factors move between regions in response to regional imbalances, there is no need for an exchange rate to perform the function of ensuring full employment by adjusting relative regional prices. Instead, full employment is achieved by factors moving to where demand is rather than by exchange rate adjustment that brings demand to where the factors are.

On the demand side, regions correspond more closely to an optimum currency area the greater the extent of inter-regional trade and the greater the degree of product market integration. In this case, there is no need for exchange rate adjustment to bring demand to producers, since producers follow market demand of their own will. The force behind this process is profit maximization. When demand is stronger and prices are higher in one market, this presents profit opportunities that induce firms to redirect output to that market with higher prices. Thus, the combination of the price system and the profit motive ensures that producers find demand, so that there is no need for relative price adjustment via exchange rates to create demand for producers in the low demand region. Indeed, the existence of different currencies could even impede this process by introducing currency conversion costs that make it more difficult to sell across regions, thereby reducing product market integration.

However, in addition to these microeconomic considerations there are also macroeconomic considerations. In an optimum currency area countries should experience broadly similar business cycles, with expansions and contractions occurring simultaneously across the regions. Moreover, not only must the stiming ' of cycles be similar, but so too must the ramplituder. Currency unions involve countries foregoing their own interest and exchange rates, so that they cannot use these variables to offset demand shocks. If a currency union is to work, demand shocks in member countries should therefore be of similar timing, magnitude, and direction so that there is no need for country specific adjustment of interest and exchange rates. 
The problem of demand shocks in a currency union is illustrated in figures I-4. Consider two economies in which the aggregate supply schedule is L-shaped, becoming vertical at the full employment level of output. In figures I and 2, countries A and B are subject to synchronized positive demand shocks of the same magnitude, and a common monetary policy can therefore offset the shock. This contrasts with figures 3 and 4 in which country $A$ is subject to a negative demand shock, while country $B$ is subject to a positive demand shock. In this situation, if the monetary authority seeks to offset the negative shock in A, it amplifies the inflationary shock in B. Conversely, if it seeks to offset the expansionary shock in B, it amplifies the contractionary shock in A.



Figure I

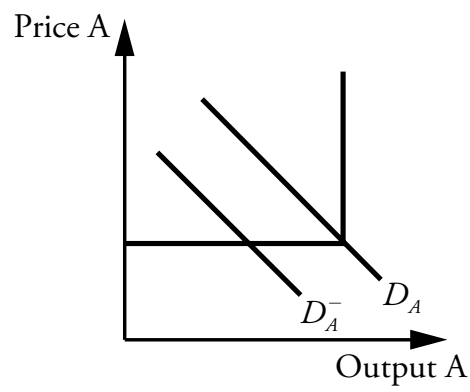

Figure 3

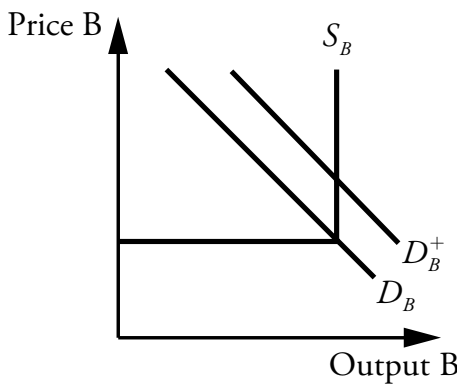

Figure 2

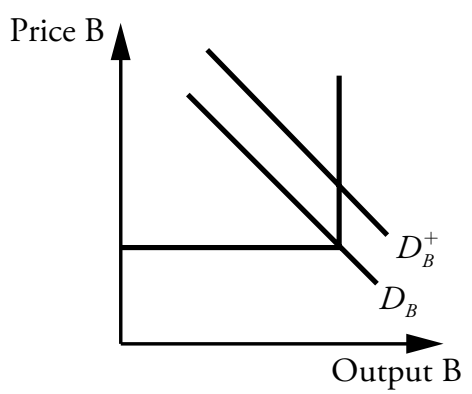

Figure 4

Figures I-4: Demand Shocks in a Currency Union

No economy is ever a perfect optimum currency area since there always exist local differences in demand conditions, and markets are imperfectly integrated owing to factor mobility frictions and goods' transportation costs. In the case of Euroland, the Euro area economy will likely become more integrated over time owing to increased factor mobility, increased financial and product market integration, and changing of trade patterns in response to elimination of foreign exchange uncertainty. ${ }^{3}$ However, an important question

3 See Rose (1999) for evidence that the creation of a currency union leads to greatly increased cross-country trade, thereby endogenously contributing to the creation of an optimum currency area. 
during this transition period is how should Europe conduct monetary policy given that it is not an optimum currency area. On this issue there is little theoretical guidance.

\section{A Macroeconomic Model of Currency Areas}

This section develops a stylized macroeconomic model that analyzes stabilization policy in a currency union. The model is an extension of a multi-sector Phillips curve model presented by Palley (1994) in which there is a long-run negatively sloped Phillips trade-off as a result of downward nominal wage rigidity in sectors with less than full employment. ${ }^{4}$ In the current application, countries substitute for sectors. Additionally, the model is now expanded to include supply-side productivity growth shocks, thereby giving insight into how supply-side disturbances impact the Phillips trade-off.

\section{I The Static Model}

The economic logic of the model is best understood by beginning with a static model. Consider a currency area in which there are $k$ countries whose product and labor markets are imperfectly integrated. Country goods market clearing is given by

$$
D_{i, t}=p_{i, t} y_{i, t}, \quad i=1, \ldots, k
$$

where $p_{i, t}=$ price of goods produced in the $i$-th country and $y_{i, t}=$ output in the $i$-th country.

Nominal demand in each country is given by

$$
D_{i, t}=D+e_{i, t}
$$

where $D_{i, t}=$ level of nominal demand in the $i$-th country in period $t, e_{i, t}=$ shock to nominal demand in the $i$-th country. $E_{t}\left[e_{i, t}\right]=0$ where $E$ is the expectations operator at time $t$. The sum of cross-country nominal demand shocks is zero, so that the level of aggregate nominal demand in the currency area as a whole is non-stochastic. However, the distribution of nominal demand across countries is uncertain.

In the above specification country nominal demand does not depend on cross-country relative prices. This is a simplifying assumption adopted for modeling purposes. Analytically, the introduction of country relative price effects would be similar to reducing the variance of demand shocks. This is because positive demand shocks push countries to full employment, thereby driving up the country price level. If relative prices mattered for the distribution of country demand, this would cause a reallocation of demand away from

4 Tobin (1972) was the first to articulate this idea. Akerlof et al. (1996) have presented a similar model of the Phillips curve. The principal difference is that they use monopolistically competitive firms who strike wage bargains with their workforces in place of a multi-sector framework. The Akerlof et al. model also makes the allocation of demand across firms dependent on relative prices. 
countries at full employment to countries receiving negative shocks and which are below full employment. Sensitivity of demand to cross-country relative prices is therefore a stabilizing mechanism.

All countries share the same production technology producing, and production is given by

$$
y_{i, t}=b N_{i, t}
$$

where $y_{i, t}=$ output in country $i$, and $N_{i, t}=$ employment in country $i$. Below full employment, prices are set by a normal mark-up. Above full employment, prices adjust to clear the goods market. Country prices are therefore given by

$$
p_{i, t}=\operatorname{Max}\left\{[1+m] w_{i, t} / b, D_{i, t} / b N_{i, t}^{s}\right\}
$$

where $m=$ mark-up, and $N_{i, t}^{s}=$ labor supply in the $i$-th country. Such a pricing structure corresponds to a situation in which each country has an L-shaped aggregate supply curve such as described in figures $\mathrm{I}-4$. Below full employment, the country product supply curve is horizontal and prices are a mark-up over average costs. At full employment, the country supply curve is vertical, and prices adjust to equate demand with the fixed level of output.

The aggregate supply of labor is fixed. However, labor is mobile between countries, but only with a lag. At the end of each period, unemployed workers move between countries so as to equalize the beginning of period cross-country unemployment rate. This is a 'quantity based allocation principle, and it means that country labor supplies are independent of country relative wages. 5 This results in ex-ante equalization of country employment rates, and country labor supplies are given by

$$
N_{i, t}^{s}=N_{i, t-1} / n_{t-1}
$$

where $n_{t-1}=$ last period's aggregate employment rate. Finally, total labor supply in the currency area is fixed and given by

$$
N_{t}^{s}=\sum_{i=1}^{k} N_{i, t}^{s}=N
$$

Given an initial level of country nominal wages, the static solutions for country output, employment, and unemployment rates are

$$
\begin{gathered}
y_{i, t}=D_{i, t} / p_{i, t}, \\
N_{i, t}=\operatorname{Min}\left\{D_{i, t} /[1+m] w_{i, t}, \quad N_{i, t}^{s}\right\}, \\
U_{i, t}=1-N_{i, t} / N_{i, t}^{s} .
\end{gathered}
$$

5 A utility theoretic justification for this allocation principle is that workers get such disutility from unemployment that they seek to maximize the likelihood of being employed. 
The logic of the model is as shown in figures I-4. Each country has an L-shaped supply schedule, the height of which is determined by the current level of country nominal wages. Negative nominal demand shocks cause unemployment, while positive demand shocks that push countries beyond full employment raise prices.

\subsection{A Model of the Inflation-Unemployment Trade-off}

The static model reveals the impact of one-time nominal demand shocks holding nominal wages constant. Tracking the dynamic evolution of economic activity requires tracking the growth of nominal demand, and specifying how nominal wages within each country respond to changing labor market conditions. This section presents the dynamic model.

The rate of aggregate nominal demand growth in each country is given by

$$
g d_{i, t}=g d+e d_{i, t}, \quad i=1, \ldots, n
$$

where $g d_{i, t}=$ rate of nominal demand growth in country $i$ in period $t, g d=$ exogenous trend rate of aggregate nominal demand growth that is controlled by the currency area monetary authority, and $e d_{i, t}=$ shock to country $i$ rate of nominal demand growth. Trend aggregate nominal demand growth, $g d$, is non-stochastic. Country nominal demand growth shocks are assumed to be drawn from a two point, zero mean, uniform distribution given by $e d^{+}>0$ and $e d^{-}<0$, where $\left|e d^{+}\right|=\left|e d^{-}\right|$. 50 percent of countries receive positive shocks of $\mathrm{ed}^{+}$, while 50 percent of countries receive negative shocks of $e d^{-}$. This assumption of a two point, zero mean, uniform distribution facilitates the process of cross-country aggregation, and enables solution for an explicit reduced form equation for the longrun Phillips curve. It also facilitates understanding the economic basis of the inflationunemployment trade-off.

The rate of productivity growth in each country is given by

$$
g s_{i, t}=g s+e s_{i, t}, \quad i=1, \ldots, n
$$

where $g s_{i, t}=$ rate of productivity growth in country $i$ in period $t, g s=$ exogenous trend rate of productivity growth, and $e_{i, t}=$ shock to country $i$ productivity growth. All countries in the currency union are assumed to have the same trend rate of productivity growth, but each is again subject to random shocks again drawn from a two point, zero mean, uniform distribution given by $e s^{+}>0$ and $e s^{-}<0$, where $\left|e s^{+}\right|=\left|e s^{-}\right|$. 50 percent of countries receive positive shocks of $e^{+}$, while 50 percent of countries receive negative shocks of $e^{-}$. Trend productivity growth, gs, is non-stochastic.

Nominal wage adjustment in each country is governed by an sunemployment regimer and a full employment r regime. Nominal wages are downwardly rigid when there is unemployment, but are perfectly flexible upward when full employment prevails. In effect, workers have ‘quasi real wage rigidity`, and are only prepared to accept real wage reductions effected through generalized inflation. The microeconomic justification for such a pattern of wage adjustment is discussed in Palley (1990 and 2003). The employment relation between firms and workers is afflicted by moral hazard, making internally sponsored 
real wage reductions problematic. Instead, workers accept real wage reductions initiated from outside the employment relation through increases in the general price level.

This two-regime nominal wage adjustment process is as follows:

$$
\omega_{i, t}= \begin{cases}g d+e d_{i, t}+\left[1-n_{t-1}\right] / n_{t-1}, & e d_{i, t}=e d^{+}>0 \\ x E\left[\pi_{t}\right], & e d_{i, t}=e d^{-}<0, \quad 0 \leq x \leq 1\end{cases}
$$

where $\omega_{i, t}=$ country nominal wage inflation, $E\left[\pi_{t}\right]=$ current period expectations of inflation, $x=$ coefficient of downward wage rigidity, and $n_{t-1}=$ last period's aggregate employment rate. The logic of equation (I2) requires careful explanation. In countries receiving positive shocks $\left(e d^{+}>0\right)$, there is full employment, and nominal wages are perfectly flexible and adjust to their market clearing level. Wages adjust by the growth of nominal demand $\left(g d+e d^{+}\right)$less the growth in real output resulting from employing the pool of unemployed workers $\left(\left[1-n_{t-1}\right] / n_{t-1}\right)$. In countries receiving negative demand shocks $\left(e d^{-}<0\right)$, there is unemployment. ${ }^{6}$ If $x=0$, inflation expectations have no effect on nominal wages in countries with unemployment. If $x>0$, inflation expectations have a positive impact on nominal wages in countries with unemployment. And if $x=1$, inflation expectations are fully incorporated into nominal wages in those countries. This last case corresponds to the case of complete downward real wage rigidity.

From an aggregate perspective, equation (I2) implies that nominal wages jump to the labor market clearing level in countries with full employment, but adjust gradually in countries with unemployment. A larger coefficient of downward wage rigidity, $x$, implies that nominal wages in countries with unemployment are more closely indexed to inflation. This serves to block growth of real aggregate demand (AD) in those countries because nominal wages and prices increase along with nominal AD.

The change in country rates of unemployment is given by

$$
d U_{i, t}=\left\{\begin{array}{lll}
-\left[1-n_{t-1}\right] & <0, & e d_{i, t}=e d^{+}>0 \\
-\left\{g d-e d^{-}-x E\left[\pi_{t}\right]\right\} n_{t-1} & >0, & e d_{i, t}=e d^{-}<0 .
\end{array}\right.
$$

Unemployment is eliminated in countries receiving positive nominal demand shocks, so that the decrease equals the beginning of period unemployment rate of $1-n_{t-1}$. The unemployment rate increases in countries receiving negative shocks. ${ }^{7}$ Trend nominal demand growth serves to reduce unemployment $(g d)$, but its effect is overwhelmed by the nega-

6 As a simplifying measure, the absolute rate of wage deflation is treated as independent of the rate of unemployment. In countries receiving positive demand shocks existing unemployment is eliminated. Thus, part of nominal demand growth translates into output and employment growth, and part translates into nominal wage and price increases. $\operatorname{Per}(8), \omega_{i, t}=g d_{i, t}-g n_{i, t}$, where $g n_{i, t}=\left[N_{i, t}-N_{i, t-1}\right] / N_{i, t-1}$. Using the definition of $g n_{i, t}$, combined with (5) yields $g n_{i, t}=\left[1-n_{t-1}\right] / n_{t-1}$.

7 It is assumed that $g d<\left|e d^{-}\right|$, so that countries receiving negative nominal demand growth shocks have increased unemployment. 
tive demand shock $\left(e d^{-}\right)$, and it is further reduced if nominal wages rise owing to inflation expectations $\left(-x E\left[\pi_{t}\right]\right)$.

The process of labor reallocation has unemployment rates being equalized across countries at the beginning of each period. Thereafter, some countries receive positive demand growth shocks that push them to full employment, while others receive negative demand growth shocks that increase unemployment. Within the greater European economy there is always some unemployment, but countries receiving positive demand growth shocks are pushed to full employment. If countries receive successive negative nominal demand growth shocks they experience successive periods with unemployment. If all countries are initially a long way away from full employment there can be an extended period in which nominal demand grows with no inflation anywhere. However, in terms of the current model such a situation represents a disequilibrium state. Over time, nominal demand growth ensures that the European economy gradually drifts to a position where countries are sufficiently close to full employment so that those receiving positive demand shocks are pushed to full employment. Within the model, steady state in the European economy is marked by a situation in which some countries experience full employment and inflation, while others experience unemployment and deflation. As shown below, the exact mix depends on the steady state rate of nominal demand growth, the variance of country demand growth shocks, and the degree of downward nominal wage flexibility.

Country price inflation is given by

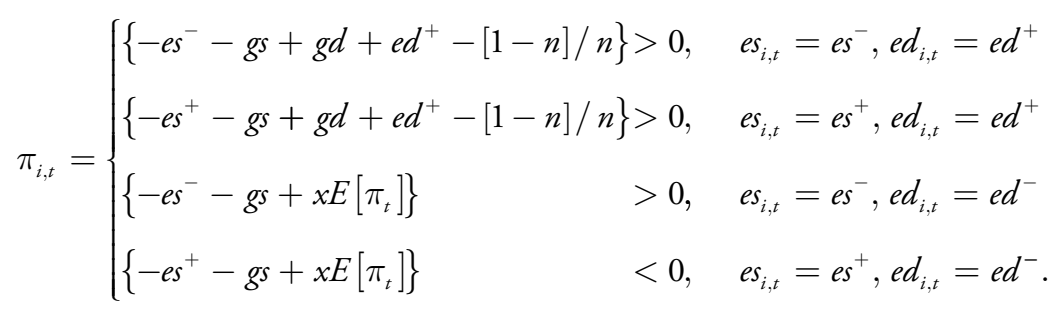

The logic of (I4) is that there are four possible combinations of supply and demand shocks, and price inflation in a country depends on the combination realized. Given the assumed independent uniform distribution of supply and demand shocks, each combination occurs with equal probability. Positive supply shocks contribute to lower price inflation, while negative supply shocks add to price inflation. Trend supply growth contributes to lower inflation. On the demand side positive demand shocks push countries to full employment, which adds to inflation. Negative demand shocks cause unemployment, but have an asymmetrically weak impact on inflation because nominal wages are downwardly rigid.

An interesting feature is that trend productivity (supply) growth has no direct impact on employment. This is because productivity growth translates into lower prices via the mark-up price equation, and this increases real demand by an amount equal to the increase in real output induced by improved productivity. The same holds for supply shocks. Positive productivity growth shocks translate into increased output, but the increase in productivity lowers prices by just enough to increase real demand by an amount equal to 
the increase in real output, leaving total employment unchanged. Negative supply shocks raise prices and lower real demand by an amount just equal to the reduction in real output, again leaving total employment unchanged.

The evolution of unemployment and inflation in the currency union is then the weighted average of country change. Given the above adjustment processes, the change in the aggregate unemployment rate and the aggregate rate of price inflation are given by

$$
\begin{gathered}
d U_{t}=-0.5\left[1-n_{t-1}\right]+0.5\left[e d^{-}-g d+x E\left[\pi_{t}\right]\right] n_{t-1}, \\
\pi_{t}=0.25\left[-e s^{-}-g s+x E\left[\pi_{t}\right]\right]+0.25\left[-e s^{+}-g s+x E\left[\pi_{t}\right]\right] \\
\quad+0.25\left[-e s^{-}-g s+g d+e d^{+}-[1-n] / n\right] \\
\quad+0.25\left[-e s^{+}-g s+g d+e d^{+}-[1-n] / n\right]
\end{gathered}
$$

where $e d=$ absolute value of demand growth shock. The currency area is in macroeconomic equilibrium when $d U_{t}=0$ and $E\left[\pi_{t}\right]=\pi_{t}{ }^{8}$ Using these conditions to solve (I5) and (I6) yields

$$
\begin{gathered}
n^{*}=1 /\left[1+e d^{-}-[1-x] g d-x g s\right], \\
U^{*}=\left[e d^{-}-[1-x] g d-x g s\right] /\left[1+e d^{-}-[1-x] g d-x g s\right], \\
\pi^{*}=g d-g s .
\end{gathered}
$$

Equation (17) shows that larger negative demand shocks lower the equilibrium employment rate. Faster trend nominal demand and supply growth raise the equilibrium employment rate. The reverse holds for the impact on unemployment which is just one minus the employment rate. The aggregate inflation rate is the difference between trend nominal demand growth and trend productivity growth.

The logic of these effects is as follows. Countries subject to negative nominal demand shocks experience higher unemployment because these shocks are not immediately accommodated owing to downward nominal wage rigidity. However, increased trend nominal demand growth can help offset the employment impact of negative nominal demand shocks.

Increases in the rate of supply growth lower inflation and inflation expectations, raising employment and lowering unemployment. This is because lower inflation expectations translate into a lower rate of nominal wage increase in countries with unemployment. This then means that the employment impact of trend nominal demand growth is stronger in these countries (i.e. it is not offset by nominal wage increases).

8 Note that though the equilibrium aggregate employment rate is constant, individual countries continue to be buffeted by employment shocks. Per (13), it is assumed that 50 percent of countries receive positive shocks, and 50 percent negative shocks. In principle, these proportions can be varied to allow for skewed distribution of shocks. 
Equations (17) to (19) embody a conventional convex Phillips curve. This Phillips relation can be obtained by substituting (19) into (17) which yields

$$
\begin{gathered}
n^{*}=1 /\{1+e d-[1-x] \pi-g s\}, \\
U^{*}=\{e d-[1-x] \pi-g s\} /\{1+e d-[1-x] \pi-g s\} .
\end{gathered}
$$

Increases in inflation, which are indirectly subject to control by the central bank through its control over the rate of nominal demand growth, can be used to increase the employment rate and lower the unemployment rate.

\subsection{Application to the Debate over ECB Policy}

The above model provides a description of the Phillips curve in a multi-country currency union setting. It can be used to illuminate why monetary policy in a currency union needs to take account of the structural factors relating to whether the currency area is an optimum currency area.

An optimum currency area can be thought of as a grouping of countries in which the cross-country demand shocks are relatively small and positively correlated. An imperfect currency area is one in which demand shocks are large and uncorrelated or even negatively correlated. In terms of the current model, the critical parameter is the absolute magnitude of the demand shock $|e d|$ which determines the variance of country demand shocks. In the current specification these demand shocks are uncorrelated across countries, and a larger value of $|e d|$ will therefore increase the dispersion of unemployment conditions across countries. In effect, the formation of the Euro area - which is not an optimum currency area - can be interpreted as equivalent to an increase in the magnitude of $|e d|$. Differentiating equation (2o.b) with respect to $e d^{-}$yields

$$
\partial U^{*} / \partial e d^{-}=1 /\left\{1+e d^{-}-[1-x] \pi-g s\right\}^{2}>0 .
$$

Thus, the Phillips curve shifts right as shown in figure 5 (p. 362). Prior to the formation of the Euro, country monetary authorities were confronted by a Phillips curve denoted $P C_{1}$. After the formation of the Euro, the ECB now confronts a Euro area Phillips curve denoted by $P C_{2}$.

The policy implications of this changed circumstance are clear. When the Bundesbank pursued a money supply growth rule consistent with an inflation target of two percent, the resulting unemployment rate was $U_{G E R}$. If the ECB persists with this same inflation target, the resulting Euro area unemployment rate will be $U_{E U R O}$ which is higher. Consequently, if the ECB is to prevent a permanent increase in the Euro area unemployment rate relative to what prevailed prior to the currency union, it will need to adjust its inflation target upward. 
Figure 5: The Impact of an Imperfect Currency Area on the Phillips Curve

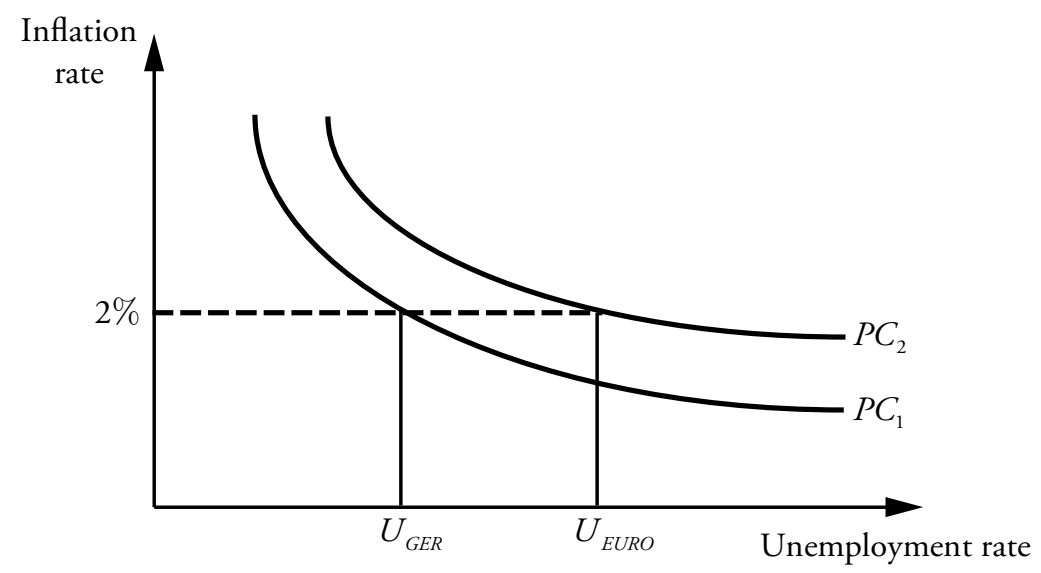

\section{Adding Heterogeneous Wage Institutions and Fiscal Policy}

There are a number of ways in which additional structure can be added to the model. One common observation is that countries may differ in their wage setting practices, with some having a greater degree of real wage rigidity. This feature is captured through the coefficient $x$, and if $x=1$ there is downward real wage rigidity. Substituting into equation (2o.b), this yields an equation for the Phillips curve given by

$$
U^{*}=\left[e d^{-}-g s\right] /\left[1+e d^{-}-g s\right] .
$$

In this case the Phillips curve is vertical at $U^{*}$.

Applied to the Euro area, we can think of some countries having downward real wage rigidity and others having some downward flexibility. In this case, the Euro area Phillips curve which confronts the ECB is a weighted average of equations (2O.b) and (2I) given by

$$
\begin{aligned}
& U^{*}=[1-\alpha]\left\{e d^{-}-[1-x] \pi-g s\right\} /\left\{1+e d^{-}-[1-x] \pi-g s\right\} \\
& +\alpha\left[e d^{-}-g s\right] /\left[1+e d^{-}-g s\right], \quad 0 \leq \alpha \leq 1
\end{aligned}
$$

where $\alpha=$ proportion of countries with downward real wage rigidity. The greater the proportion of countries with real wage rigidity, the more vertical the Euro area Phillips curve. Of course, if all countries have full inflation indexation of nominal wages, then there is no Phillips trade-off, and joining the Euro area has no implications in terms of lost capacity to exploit a trade-off.

A second way in which structure can be added is through inclusion of automatic fiscal stabilizers. These automatic stabilizers serve to reduce the size of country nominal demand growth shocks as follows: 


$$
e d_{i, t}^{\prime}=\operatorname{qed}_{i, t}, \quad 0 \leq q \leq 1
$$

where $e d_{i, t}^{\prime}=$ effective nominal demand growth shock, and $q=$ automatic stabilizer coefficient. In effect, a smaller coefficient $q$ serves to reduce the effective size of the nominal demand growth shock (i.e. leans against the wind).

Fiscal policy is not usually viewed as relevant for the Phillips curve and the inflationunemployment trade-off. However, the above micro-founded model reveals that it is important since geographically based automatic stabilizers reduce the dispersion of demand shocks, thereby shifting the Phillips curve to the left. This speaks to the benefit of modifying the Stability and Growth Pact to the extent that it interferes with country automatic fiscal stabilizers.

\section{Asset Based Reserve Requirements}

A third policy for improving macroeconomic management is to introduce country-specific asset based reserve requirements (ABRR). A major problem with currency unions is the loss of the exchange rate and interest rate as instruments of country policymaking. Countrybased ABRR represent a means of restoring some control over national interest rates. The explicit workings of an ABRR system have been explored in Palley (2000 and 2004) in the context of national monetary policy and controlling asset price bubbles. However, ABRR can be extended to include a geographic dimension by making the required reserve ratio a function of both the asset type and its geographic location, and this feature makes them useful for policy in currency unions. ${ }^{9}$

$A B R R$ are a form of balance sheet regulation that ties asset categories together by linking required reserve holdings to the composition of assets (i.e. they are an asset-to-asset link). They can be contrasted with traditional liability based reserve requirements (LBRR) that tie required reserve holdings to the composition of liabilities (i.e. they are a liabilityto-asset link). The microeconomic logic of ABRR is easily illustrated through a model of a generic financial firm. Consider a generic perfectly competitive financial firm with constant returns technology and non-stochastic withdrawals. Under a system of ABRR the representative firm's profit maximization program is given by

$$
\begin{gathered}
\operatorname{Max}_{L, H, D, T, F} V=i_{L} L+i_{H} H-\left[a_{L}+p_{L}\right] L-\left[a_{H}+p_{H}\right] H \\
-\left[i_{D}+a_{D}\right] D-\left[i_{T}+a_{T}\right] T-\left[i_{F}+a_{F}\right] F
\end{gathered}
$$

subject to

$$
\left[1+k_{L}\right] L+\left[1+k_{H}\right] H=D+T+F
$$

where $L=$ investment loans, $H=$ consumer loans, $D=$ short term deposits, $T=$ long term deposits, $F=$ Money market borrowing $(F>0)$ or lending $(F<0), i_{j}=$ interest rate

9 This suggestion is made by Palley (2004: 50). 
( $j=L, H, D, T, F), a_{j}=$ constant marginal cost per dollar of administering loans and liabilities $(j=L, H, D, T, F), p_{j}=$ probability per dollar of default on loans $(j=L, H)$, and $k_{j}=$ reserve requirement ratio $(j=L, H), k_{L}>k_{H}>0$. Equation (24) is the profit function, while equation (24.A) is the balance sheet constraint. Substituting the constraint into (24) and differentiating with respect to the choice variables $(D, T, H, F)$ yields four first order conditions. Satisfaction of these conditions implies the following structure of interest rates expressed in terms of the money market rate:

$$
\begin{gathered}
i_{L}=\left[i_{F}+a_{F}\right]\left[1+k_{L}\right]+a_{L}+p_{L}, \\
i_{H}=\left[i_{F}+a_{F}\right]\left[1+k_{H}\right]+a_{H}+p_{H}, \\
i_{D}=i_{F}+a_{F}-a_{D}, \\
i_{T}=i_{F}+a_{F}-a_{T} .
\end{gathered}
$$

The money market rate, which is set by the monetary authority, underpins the entire structure of interest rates. The rates on investment and consumer loans are established as markups over the money market rate. These mark-ups take account of the respective costs of administering loans, as well as the respective expected loan default losses.

In an ABRR system, the required reserve ratio affects the relative rates charged on loans. Assets can also be zero-rated, in which case their interest rate is unaffected. A higher required reserve ratio raises loan rates. The reason is that $A B R R$ oblige banks to borrow more than a dollar to make one dollar of loans, and they now charge borrowers for the extra that they must borrow. Examination of equations (25.A)-(25.D) reveals the microeconomic allocative effects of ABRR. Financial intermediaries must acquire additional funds to make loans, and they pass on the costs of these additional funds to borrowers. ABRR raise loan rates for a given money market rate. If reserve requirements differ by loan type, then the demand for loans with the higher reserve requirement will fall relative to that with the lower reserve requirement.

The above mechanism reveals how ABRR can be used to influence the microeconomic allocation of credit. This is done by changing the relative price of different types of credit without changing the general level of interest rates. Such a credit allocation effect has some similarity with selective credit controls. However, selective credit controls are a ‘quantity، based regulation, which leads to rationing problems. ABRR allows the market to allocate credit at a price that is implicitly determined by the monetary authority.

If the menu of financial intermediary assets is further disaggregated, the monetary authority can in principle make even finer decisions about pricing of credit and asset returns. A major concern today is over-heated real estate markets. Under existing arrangements controlling such over-heating requires raising the general level of interest rates, with all its adverse consequences for the entire macroeconomy. In a system with ABRR, the monetary authority can narrowly target the real estate sector by raising reserve requirements on mortgage loans. 
In effect, ABRR can provide monetary authorities with multiple independent additional tools of monetary control that can supplement existing control over the short-term interest rate. In terms of Tinbergen's (1952) targets and instruments approach to macroeconomic stabilization policy, ABRR can provide additional independent policy instruments that allow policy-makers to focus on additional economic targets. It is this feature that potentially makes ABRR useful for Euroland. Euro area policy-makers are wrestling with the loss of the exchange rate and national interest rates as instruments of policy. The goals of macroeconomic stabilization have remained unchanged, but policy-makers now have a reduced set of policy instruments. A system of ABRR can help remedy this. Not only can they be applied on different asset categories within each country, but reserve requirements can also differ across countries. This would enable policy-makers to re-introduce cross-country interest rate differentials. These cross-country interest differentials would be conditioned on the observed country nominal demand growth shocks, $e d_{i, t}$.

In terms of the above microeconomic model, such geographic differentiation would give rise to the following pattern of rates:

$$
\begin{aligned}
& i_{L, j}=\left[i_{F}+a_{F}\right]\left[1+k_{L, j}\right]+a_{L}+p_{L}, \\
& i_{H, j}=\left[i_{F}+a_{F}\right]\left[1+k_{H, j}\right]+a_{H}+p_{H}
\end{aligned}
$$

where $j=j$-th country. Monetary policy would then respond so that countries receiving negative nominal demand growth shocks had lower reserve requirements. One problem is that borrowers would have an incentive to arbitrage cross-country loan rate differences and borrow in countries with the lowest reserve requirement ratio. That suggests that geographically distinguished reserve requirements would work best where loans are secured by geographically situated collateral. The real estate market, which is a major concern of policy-makers, is the perfect candidate. This is because loans are secured by mortgages, and therefore the reserve requirement can be tied to this feature and would not be susceptible to jurisdictional arbitrage. ${ }^{\text {IO }}$

In sum, ABRR are a valuable tool of monetary policy that can apply to the Euro area as a whole. Additionally, some categories of lending (particularly mortgage lending) can be made subject to geographically tied ABRR, which could help European monetary authorities address inflationary pressures that are specific to individual countries. Moreover, such geographic ABRR can also be used to stimulate activity in countries that are subject specific deflationary pressures. This can be done by sting a negative reserve requirement, thereby implicitly subsidizing lending.

Io In addition to this important macroeconomic stabilization benefit there are significant microeconomic benefits of reserve requirements. These microeconomic benefits are outside the scope of the current paper, and the reader is referred to Palley (2004) where they are discussed extensively. That paper also discusses how a system of ABRR would be institutionally constructed. 


\section{A Digression on Downward Nominal Wage Rigidity and Nominal Debt Effects}

The static model presented in section 3 treats downward nominal wage rigidity as an impediment to full employment. As specified, if nominal wages were perfectly flexible, then the economy would jump to full employment if nominal wages were to fall sufficiently in sectors with unemployment. This specification ignores the possibility of inside nominal debt effects, which can reverse the sign of the effect of nominal wage reductions on employment and output (Tobin 1980, Palley 1996 and 1999). If there is inside nominal debt and a strong Fisher debt effect, lower nominal wages and prices may reduce the level of real aggregate demand and lower employment. This can be captured by re-specifying equation (I), and making country nominal demand a negative function of the level of inside debt burdens. A possible specification is as follows:

$$
D_{i, t}=D\left(B_{i, t} / w_{i, t}, \ldots\right)+e_{i, t}
$$

where $B_{i, t}=$ level of inside debt in country $i$. The sign above represents the assumed sign of the partial derivative. Using the expression for the price level given by equation (4), real country demand is then given by

$$
D_{i, t} / p_{i, t}=\left[D\left(B_{i, t} / w_{i, t}, \ldots\right)+e_{i, t}\right] b /[1+m] w_{i, t} .
$$

Differentiating with respect to the nominal wage yields

$$
\begin{gathered}
\partial\left(D_{i, t} / p_{i, t}\right) / \partial\left(w_{i, t}\right)=\left\{\left[-D^{\prime} B_{i, t} / w_{i, t}^{2}\right]\left[b /[1+m] w_{i, t}\right]\right\} \\
-\left[D\left(B_{i, t} / w_{i, t}, \ldots\right)+e_{i, t}\right] b /[1+m]_{<}^{>} 0 .
\end{gathered}
$$

The first term in curly parentheses is positive, reflecting the Fisher debt effect. The second term is negative, reflecting the Pigou effect. If the first term dominates, higher nominal wages increase real demand and employment, so that reducing nominal wages is a disastrous employment strategy.

With regard to the dynamic model in section 3, debt burden effects enter at two points. First, inflation can strengthen nominal demand growth by reducing the real interest rate through the Tobin (1965)-Mundell (1963) effect and by eroding nominal debt burdens. This effect of inflation can be captured by re-specifying country nominal demand growth as

$$
g d_{i, t}=g d+\beta E[\pi]_{t}+e d_{i, t}, \quad 0<\beta<1 .
$$

Second, these nominal demand growth impacts then affect the evolution of the unemployment rate. This unemployment effect is captured by modifying equation (I3) as follows:

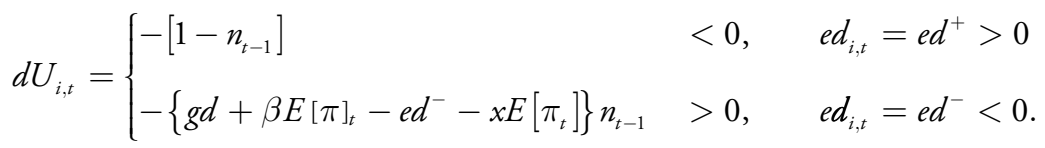


Now, there is an additional positive effect of inflation expectations working via nominal demand growth, and this effect counters the impact of inflation expectations on nominal wage costs. In terms of figure $\mathrm{I}$, both the country demand and supply schedules are shifting upward as a result of inflation expectations. If $\beta>x$, the demand schedule shifts up by more than the supply schedule, in which case inflation expectations reduce unemployment in those countries that are below full employment.

Taking account of these two modifications, the steady state rates of employment, unemployment, and inflation are given by

$$
\begin{gathered}
n^{*}=1 /\left\{1+e d^{-}-[1+\beta-x] g d+[\beta-x] g s\right\}, \\
U^{*}=\left\{e d^{-}-[1+\beta-x] g d+[\beta-x] g s\right\} \\
/\left\{1+e d^{-}-[1+\beta-x] g d+[\beta-x] g s\right\}, \\
\pi^{*}=[g d-g s] /[1-\beta] .
\end{gathered}
$$

Now, a given rate of nominal demand growth generates higher inflation, but it also generates a higher employment rate, and an even lower unemployment rate. In effect, nominal debt burden and Tobin-Mundell effects increase the bang from nominal demand growth owing to positive feedback between nominal demand growth and inflation. Higher inflation then feeds through to raise nominal wages, and rising nominal wages reduce debt burdens and add to country nominal demand, thereby raising the employment rate and lowering the unemployment rate.

In sum, inclusion of nominal debt effects changes the policy recommendation for the static model, but leaves intact the recommendations for the dynamic model. Inflation remains a valuable tool for reducing unemployment because it adds to aggregate nominal demand growth by lowering real interest rates and eroding debt burdens. In the presence of strong Fisher inside debt effects, a higher nominal wage level and faster nominal wage inflation are both good for reducing unemployment.

\section{Conclusion}

Euroland policy-makers are wrestling with how to improve macroeconomic outcomes within the Euro area. There is widespread agreement that the Euro is an economically nonoptimal currency area. The paper shows that monetary policy in a non-optimal currency area should adopt a higher inflation target to avoid higher unemployment resulting from lack of correlation of demand shocks across countries. It also shows the importance of geographically triggered automatic stabilizers that can improve the aggregate inflationunemployment trade-off. Lastly, the paper argues for the creation of an asset based reserve requirement system of financial intermediary regulation. Not only would such a system enable policy authorities to impact relative loan rates and rates of return within countries, they would also be able to impact the structure of cross-country interest rates by having 
different cross-country reserve requirements. Such a system can help address the problem of loss of policy instruments that results from formation of a currency union.

\section{References}

Akerlof, George A. / Dickens, William T. / Perry, George L. (1996): The Macroeconomics of Low Inflation, Brookings Papers on Economic Activity, No. I, pp. I-76

Angeloni, Ignazio / Gaspar, Victor/Tristani, Orest (1999): The Monetary Policy Strategy of the ECB, in: Cobham, David/Zis, George (eds.), From EMS to EMU, London: Macmillan, pp. 3-42

Bayoumi, Tamim / Eichengreen, Barry (1993): Shocking Aspects of European Monetary Integration, in: Torres, Francisco/ Giavazzi, Francesco (eds.), Adjustment and Growth in the European Monetary Union, Cambridge: Cambridge University Press, pp. 193-229

Flaschel, Peter / Proaño-Acosta, Christian/Semmler, Willi (2005): Baseline Keynesian Disequilibrium Dynamics and the Phillips Curve: Comparing the USA and the Euro-area, paper presented at a conference on "Macroeconomics and Macroeconomic Policies: Alternatives to the Orthodoxy« of the Research Network Alternative Macroeconomic Policies, Berlin, Germany, 28-29 October, 2005

Kenen, Peter B. (1969): The Theory of Optimum Currency Areas: An Eclectic View, in: Mundell, Robert / Swoboda, Alexander (eds.), Monetary Problems of the International Economy, Chicago: University of Chicago Press, pp. 4I-60

McKinnon, Ronald I. (1963): Optimum Currency Areas, in: American Economic Review, Vol. 53, No. 4, pp. 717-725

Mundell, Robert (196I): The Theory of Optimum Currency Areas, in: American Economic Review, Vol. 5I, No. 4, pp. 657-665

Mundell, Robert (1963): Inflation and the Real Interest Rate, in: Journal of Political Economy, Vol. 7I, No. 3, 280-283

Palley, Thomas I. (1990): A Theory of Downward Wage Rigidity: Job Commitment Costs, Replacement Costs, and Tacit Coordination, in: Journal of Post Keynesian Economics, Vol. I2, No. 3, pp. 466-486

Palley, Thomas I. (1994): Escalators and Elevators: A Phillips Curve for Keynesians, in: Scandinavian Journal of Economics, Vol. 96, No. I, pp. III-II6

Palley, Thomas I. (1996): Post Keynesian Economics: Debt, Distribution, and the Macro Economy, London: Macmillan Press

Palley, Thomas I. (1999): General Disequilibrium Analysis with Inside Debt, in: Journal of Macroeconomics, Vol. 2I, No. 4, pp. 785-804

Palley, Thomas I. (2000): Stabilizing Finance: The Case for Asset Based Reserve Requirements, Report in the Financial Markets and Society series, Philomont, VA.: Financial Markets Center

Palley, Thomas I. (2003): The Backward Bending Phillips Curve: Wage Adjustment with Opportunistic Firms, The Manchester School of Economic and Social Studies, Vol. 7I, No. I, pp. $35-50$ 
Palley, Thomas I. (2004), Asset Based Reserve Requirements: Reasserting Domestic Monetary Control in an Era of Financial Innovation and Instability, in: Review of Political Economy, Vol. I6, No. I, pp. 43-58

Rose, Andrew K. (1999): One Money, One Market: Estimating the Effect of Common Currencies on Trade, NBER Working Paper, No. 7432

Tinbergen, Jan (1952): On the Theory of Economic Policy, Amsterdam: North-Holland

Tobin, James (1965): Money and Economic Growth, in: Econometrica, Vol. 33, No. 4, pp. 671684

Tobin, James (1972): Inflation and Unemployment, in: American Economic Review, Vol. 62, No. I-2, pp. I-I8

Tobin, James (1980): Asset Accumulation and Economic Activity, Chicago: Chicago University Press 
